Tropical Journal of Pharmaceutical Research March 2021; 20 (3): 627-632

ISSN: $1596-5996$ (print); 1596-9827 (electronic) (C) Pharmacotherapy Group, Faculty of Pharmacy, University of Benin, Benin City, 300001 Nigeria.

\title{
Antidiabetic effects of ethanol extract of Uromastyx hardwickii Smith (Agamidae) skin on streptozotocin- induced diabetes mellitus in mice
}

\author{
Waqas A Shams ${ }^{1}$, Samuel 0 Onoja ${ }^{2 *}$, Gauher Rehman ${ }^{1}$, Saif U Islam¹, \\ Khurshaid Khan ${ }^{1}$, Muhmmad Ibrar ${ }^{1}$, Saima B Sia ${ }^{1}$, Saba G Ayaz ${ }^{1}$, Sajid Ali ${ }^{3}$, \\ Muhammad Israr ${ }^{1}$, Aziz ullah ${ }^{1}$, Dawood Safi ${ }^{1}$ \\ ${ }^{1}$ Department of Zoology, Abdul Wali Khan University, Mardan, Khyber Pakhtunkhwa 23200, Pakistan, ${ }^{2}$ Department of \\ Veterinary Physiology and Pharmacology, Michael Okpara University of Agriculture, Umudike, PMB 7267, Umuahia, Abia State, \\ Nigeria, ${ }^{3}$ Department of Chemistry, University of Malaknd, Khyber Pakhtunkhwa 18800, Pakistan
}

*For correspondence: Email: onoja.samuel@mouau.edu.ng; samonreal@yahoo.com; Tel: +234-8030613032

\begin{abstract}
Purpose: To investigate the in vivo hypoglycemic potential of the ethanol extract of Uromastyx hardwickii skin (EEUHS).

Methods: Streptozotocin-induced diabetic mice received graded doses (100 and $200 \mathrm{mg} / \mathrm{kg}$ ) of EEUHS for oral glucose tolerance and hypoglycemic test. The effects of EEUHS on body weight gain, urea, creatinine, cholesterol and hemoglobin concentration were also investigated.

Result: The blood glucose concentrations of the EEUHS-treated groups were diminished $(p<0.05)$ relative to the diabetic control group. The urea, creatinine and cholesterol levels of the EEUHS-treated groups were lower $(p<0.05)$, but their hemoglobin concentrations were higher $(p<0.05)$ relative to the diabetic control group.

Conclusion: The EEUHS elicits hypoglycemic effects and ameliorates complications of diabetes mellitus in streptozotocin-induced diabetic mice. This suggests that EEUHS can potentially be developed for the management of diabetic patients.
\end{abstract}

Keywords: Anemia, Antidiabetic, Lizard, Glibenclamide, Streptozotocin, Uromastyx hardwickii, Weight loss

\begin{abstract}
This is an Open Access article that uses a fund-ing model which does not charge readers or their institutions for access and distributed under the terms of the Creative Commons Attribution License (http://creativecommons.org/licenses/by/4.0) and the Budapest Open Access Initiative (http://www.budapestopenaccessinitiative.org/read), which permit unrestricted use, distribution, and reproduction in any medium, provided the original work is properly credited.

Tropical Journal of Pharmaceutical Research is indexed by Science Citation Index (SciSearch), Scopus, International Pharmaceutical Abstract, Chemical Abstracts, Embase, Index Copernicus, EBSCO, African Index Medicus, JournalSeek, Journal Citation Reports/Science Edition, Directory of Open Access Journals (DOAJ), African Journal Online, Bioline International, Open-J-Gate and Pharmacy Abstracts
\end{abstract}

\section{INTRODUCTION}

Diabetes mellitus (DM) is a chronic noncommunicable disease caused by insulin resistance, insulin deficiency and/or combination of both factors [1]. It has affected over 463 million people worldwide [2]. About $75 \%$ of diabetic patients are within the working age group (24 64 years old). The impact of DM on global economy is estimated at over US\$ 827 billion annually [3]. Poorly-managed diabetic conditions predispose to other health complications and about $11.3 \%$ of death are attributed to diabetes globally [2]. 
The control and treatment of DM involve changes in lifestyle, insulin therapy and oral hypoglycemic agents. Some oral hypoglycemic agents used in the clinical management of DM are sulfonylureas, thiazolidinediones, alphaglucosidase inhibitors, biguanides and dipeptidyl peptidase-4 inhibitors. The clinical efficacy and patients' compliance with the use of these drugs have been hampered by their side-effects such as anorexia, diarrhea, nausea, vomiting, nausea, cholestatic jaundice, weight gain, stomach upset, agranulocytosis, aplastic and hemolytic anemia, increased cardiovascular mortality, generalized hypersensitivity and skin reactions [4]. Aside the aforementioned side-effects, orthodox drugs are expensive and not readily available. Hence, a good proportion of the population use traditional medicines in the care of DM [5].

In ethnomedicine, DM is managed via zootherapy in countries like Brazil, Pakistan, China, India, Argentina etc [6,7]. About 1500 animal species are used in zootherapy [8]. Some of the diseases treated via zootherapy are helminthosis, cancer, asthma, pain, fever, pneumonia, piles, gastric ulcer and DM [8]. In Pakistan, Uromastyx hardwickii is used in zootherapy. Uromastyx hardwickii is commonly called "Hardwicke's spiny-tailed lizard" or "Indian spiny-tailed lizard" and member of the family Agamidae [9]. It is a diurnal, ground-dwelling and herbivorous lizard that lives in burrows. It is found in Saharo-Sindic region of the Arabian Peninsula [9]. The flesh is consumed by some natives of Pakistan as a supplement for diabetic management [8]. The oil obtained from the body fat is used as embrocation oil and aphrodisiac for the treatment of impotence by the natives of India and Pakistan [9]. The in vitro antidiabetic effects of the ethanol extract of $U$. hardwickii skin have been reported [10]. There is dearth of information on the in vivo hypoglycemic activities of $U$. hardwickii skin extract. This study interrogated the in vivo hypoglycemic activities of the ethanol extract of $U$. hardwickii skin.

\section{EXPERIMENTAL}

\section{Capture of $U$. hardwickii}

Four (4) mature $U$. hardwickii of both sexes were captured from the desert and semi-desert region of Pakistan. The $U$. hardwickii was authenticated by $\mathrm{Dr}$ G. Rehman and stuffed specimen was deposited in the museum of the Department of Zoology, Abdul Wali Khan University. The $U$. hardwickii were managed as recommended by the National Research Council guidelines [11]. The ethical clearance (no. AWKUM/ZOO/ 2018/1770) for the study was obtained from the
Ethical Committee, of the Department of Zoology, Abdul Wali Khan University.

\section{Preparation of extract of $U$. hardwickii skin}

Four adult $U$. hardwickii of both sexes were placed in a box containing diethyl ether (soaked in cotton wool) for few minutes and euthanized via cervical dislocation. The skin was excised, dried laboratory bench, ground into coarse powder, extracted with ethanol in Soxhlet apparatus and evaporated with rotary evaporator [10]. The ethanol extract of $U$. hardwickii skin (EEUHS) was stored at $4{ }^{\circ} \mathrm{C}$ in a refrigerator.

\section{Animals}

Fifty (50) mature male healthy albino mice (6-8 weeks of age) weighing 28 - $35 \mathrm{~g}$ were used for this study. The animals were kept in clean and dry plastic cages, with natural light/dark cycle at $25 \pm 2{ }^{\circ} \mathrm{C}$ environmental temperature and 45 $55 \%$ relative humidity. The animals were fed with standard pellet diet and water ad libitum. The mice were handled with minimal pain [11].

\section{Acute toxicity test}

The "Up and Down" method of oral acute toxicity test was used evaluate the toxicity of EEUHS. The upper dose limit was $2000 \mathrm{mg} / \mathrm{kg}$.

\section{Blood glucose concentration (BGC) assay}

The BGC of the mice were assay using AccuChek glucometer test kit (Roche, Germany) using blood samples drawn from the tail vein upon a tail snip.

\section{Induction of experimental DM}

Streptozotocin (STZ) (Fine Chemicals Pvt Ltd, Biosar) was dissolved in citrate buffer and injected intraperitoneal once at dose of $50 \mathrm{mg} / \mathrm{kg}$ to fasted mice. The fasting BGC was evaluated 48 hours post STZ administration with AccuChek glucometer test kit (Roche, Germany) and mice with BGC above $150 \mathrm{mg} / \mathrm{dL}$ were recruited for the experiment [12].

\section{Oral glucose tolerance test (OGTT)}

Twenty (20) STZ-induced hyperglycemic mice were used for the experiment. The mice were randomly assigned to 4 groups (A - D) of 5 mice each. Group A (diabetic control) received normal saline, groups $B$ and $C$ received EEUHS 100 and $200 \mathrm{mg} / \mathrm{kg}$, respectively, while group D received glibenclamide $2 \mathrm{mg} / \mathrm{kg}$ (positive control). All treatments were given via the oral route with the 
aid of a gastric gavage. Thirty (30) minutes posttreatment, glucose load $(2000 \mathrm{mg} / \mathrm{kg})$ was administered to each mouse Thereafter, BGC was evaluated at $30,60,90$ - and 120-minutes post-glucose load.

\section{Evaluation of in vivo hypoglycemic activity of EEUHS}

We used 25 mice (5 normoglycemic and 20 hyperglycemic mice) for this experiment. The 5 normoglycemic mice were assigned to Group A (normal control) which received normal saline, 5 $\mathrm{ml} / \mathrm{kg}$. The 20 hyperglycemic mice were randomly assigned to 4 groups ( $n=5, B-E$ ). Group B (diabetic control) received normal saline; groups $C$ and $D$ received EEUHS 100 and $200 \mathrm{mg} / \mathrm{kg}$ respectively, while group $\mathrm{E}$ received glibenclamide $2 \mathrm{mg} / \mathrm{kg}$. The treatment were given once daily for 17 consecutive days via gastric gavage. Fasting BGC was assayed on days 1, 4, 10 and 17 with Accu-Chek active glucometer test kit (Roche, Germany). The mice were weighed on days 1, 4, 10 and 17. Twenty-four (24) hours after the last treatment on day 17, the mice were fasted for 16 hours and blood samples were drawn via the retro-orbital plexus into EDTA bottles for hemoglobin concentration determination and also into plain bottles for serum biochemical (blood urea nitrogen (BUN), creatinine and cholesterol) analysis.

\section{Determination of hemoglobin, BUN, creatinine and cholesterol levels}

Cyanomethemoglobin method was used in the determination of hemoglobin concentration [13]. The serum concentration of BUN, creatinine and cholesterol were assayed spectrophotometrically using commercial reagent kits (Randox Laboratories, United Kingdom).

\section{Statistical analysis}

Data generated were analyzed using one-way analysis of variance (ANOVA). Mean differences were separated using Tukey's test (SPSS 22.0 software) and significance difference was accepted at $p<0.05$.

\section{RESULTS}

\section{Effect of EEUHS on OGTT of STZ-induced diabetic mice}

The effects of EEUHS on the OGTT on STZinduced diabetic mice are presented in Figure 1. At 120 minutes, the BGC of the EEUHS and glibenclamide-treated groups were lower $(p<$ 0.05 ) than the BGC of the diabetic control group.
The EEUHS produced dose-dependent decrease in the BGC.

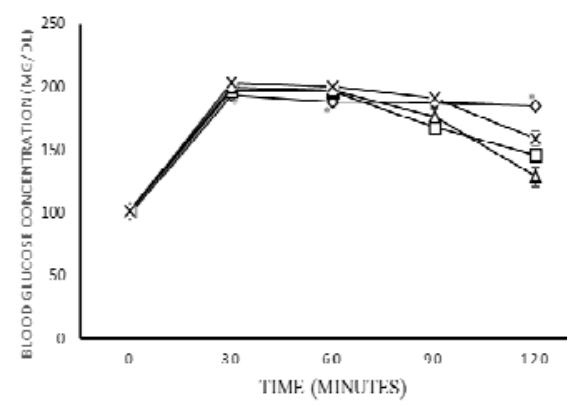

Figure 1: Effect of EEUHS on OGTT of STZ-induced diabetic mice; ${ }^{*} p<0.05$ relative to other treatment groups; EEUHS = ethanol extract of Uromastyx hardwickii skin; $-\diamond-=$ diabetic control; $-\square-=$ EEUHS $100 \mathrm{mg} / \mathrm{kg} ;-\Delta-=$ EEUHS $200 \mathrm{mg} / \mathrm{kg} ; \quad-x-=$ glibenclamide $2 \mathrm{mg} / \mathrm{kg}$

\section{Effect of EEUHS on fasting BGC of STZ- induced diabetic mice}

On days 10 and 17, the BGC of EEUHS-treated groups were diminished $(p<0.05)$ relative to the BGC of diabetic control group. The EEUHS produced time-dependent decline in the BGC of the treated groups.

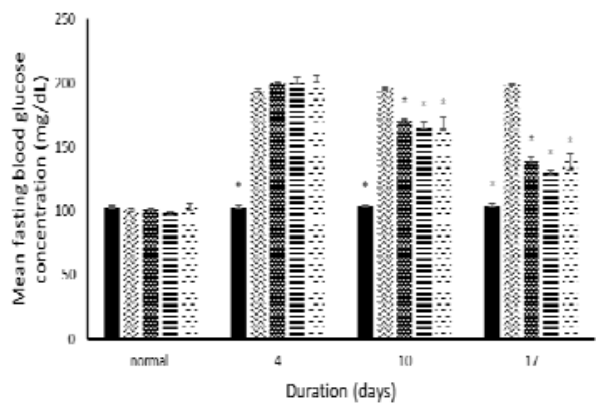

Figure 2: Effect of EEUHS on fasting BGC of STZinduced diabetic mice. ${ }^{*} p<0.05$ relative to the diabetic control group; EEUHS = ethanol extract of Uromastyx hardwickii skin; = normal control; $\approx=$ diabetic

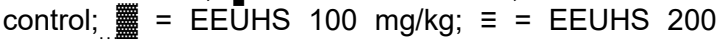
$\mathrm{mg} / \mathrm{kg} ;$; = glibenclamide $2 \mathrm{mg} / \mathrm{kg}$

\section{Effect of EEUHS on body weight of STZ- induced diabetic mice}

The normal control, EEUHS (100 and $200 \mathrm{mg} / \mathrm{kg}$ ) and glibenclamide-treated groups gained weight while the diabetic control group lost weight throughout the period of the experiment (Figure 3 ). The percentage weight gain of the EEUHS and glibenclamide-treated groups on days 10 and 17 were higher $(p<0.05)$ relative to the diabetic control group. 


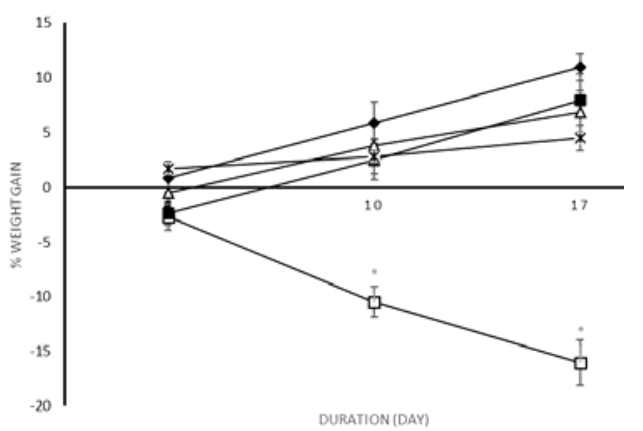

Figure 3: Effect of EEUHS on body weight of STZinduced diabetic mice. ${ }^{*} p<0.05$, relative to other treatment groups; EEUHS $=$ ethanol extract of Uromastyx hardwickii skin; - - = normal control; - - - = diabetic control; $-\Delta-=$ EEUHS $100 \mathrm{mg} / \mathrm{kg}$; $-\mathbf{-}-=$ EEUHS $200 \mathrm{mg} / \mathrm{kg}$; -x- = glibenclamide $2 \mathrm{mg} / \mathrm{kg}$ Effect of EEUHS on serum urea, creatinine
and cholesterol, and hemoglobin concentrations of STZ-induced diabetic mice

The BUN, creatinine and cholesterol concentrations of the normal control, EEUHS (100 and $200 \mathrm{mg} / \mathrm{kg}$ ) and glibenclamide-treated groups were diminished $(p<0.05)$ when related to the diabetic control group (Table 1). The hemoglobin concentration of the normal control, EEUHS (100 and $200 \mathrm{mg} / \mathrm{kg}$ ) and glibenclamidetreated were elevated $(p<0.05)$ when related to the diabetic control group.

\section{DISCUSSION}

We investigated the acute toxicity and hypoglycemic effects of EEUHS on STZ-induced diabetic mice. The EEUHS was well tolerated by the mice and the $\mathrm{LD}_{50}$ was greater than 2000 $\mathrm{mg} / \mathrm{kg}$. The EEUHS reduced BGC, BUN, creatinine and cholesterol levels, and increased hemoglobin concentration and weight gain of STZ-induced diabetic mice.

Oral glucose tolerant test evaluated the influence of EEUHS on the post-prandial glucose metabolism [14]. The first $30 \mathrm{~min}$ post glucose load was the absorptive phase while the 90 and
120 min was the assimilation or the storage phase. The elevated BGC in the diabetic control group at $120^{\text {th }}$ minutes is linked to glucagon secretion. Non-inhibition of glucagon secretion accompanies insulin deficiency and is incriminated in post-prandial hyperglycemia in DM [15]. The diminished BGC of the EEUHSand glibenclamide-treated groups might be linked to enhanced incretin effect [15]. This finding indicates that the EEUHS can effectively manage post-prandial hyperglycemia in a diabetic patient. STZ is a nitrosourea analogue with alkylating and antimicrobial properties that cause necrosis of beta cells of the pancreas. It causes insulinopenia and $\mathrm{DM}$ in rodents [16]. It accumulates in beta cells through GLUT-2 transporters. Treatment of mice with STZ caused hyperglycemia which indicates insulinopenia and diabetic condition. The EEUHS administration caused mild dose-dependent decline in BGC of the treated mice on days 10 and 17 (Figure 2). The mechanology of the hypoglycemic effects of EEUHS could be via reduction in gut glucose absorption, enhanced hepatic glucose uptake and increased insulin secretion or sensitivity. The in vitro anti-glucosidase and antiamylase activities of EEUHS have been reported [10]. Glucosidase and amylase catalyze carbohydrate digestion in the gut. Agents that inhibit the activities of these enzymes are known to reduce glucose absorption and post-prandial hyperglycemia, and hence exploited in the care of DM. The hypoglycemic potential of acarbose is based on its inhibition of glucosidase and amylase [17]. Another possible mechanology of the hypoglycemic effects of EEUHS, is the enhanced hepatic and muscular uptake of glucose. Liver and partly muscles are the major storage organs of glucose in the form of glycogen.

Elevated uptake of glucose by muscle and liver lead to hypoglycemia and some antidiabetic drugs such as metformin exhibit this mechanism of action [18]. The EEUHS might have also elicited its antihyperglycemic potential via the enhanced insulin secretion and/or increased

Table 1: Effect of EEUHS on BUN, creatinine, cholesterol, and hemoglobin concentration of STZ-induced diabetic mice (mean $\pm S D, n=5)$

\begin{tabular}{lcccc}
\hline Treatment & BUN (mg/dL) & $\begin{array}{c}\text { Creatinine } \\
\text { (mg/dL) }\end{array}$ & $\begin{array}{c}\text { Cholesterol } \\
\text { (mg/dL) }\end{array}$ & $\begin{array}{c}\text { Hemoglobin } \\
(\mathbf{g} / \mathbf{d L})\end{array}$ \\
\hline Normal control & $22.70 \pm 0.61^{*}$ & $0.47 \pm 0.01^{*}$ & $66.99 \pm 0.86^{*}$ & $14.19 \pm 0.20^{*}$ \\
Diabetic control & $35.45 \pm 0.51$ & $1.50 \pm 0.09$ & $122.26 \pm 2.16$ & $8.83 \pm 0.35$ \\
EEUHS (100 $\mathrm{mg} / \mathrm{kg})$ & $26.20 \pm 0.78^{*}$ & $0.43 \pm 0.02^{*}$ & $68.65 \pm 0.58^{*}$ & $11.61 \pm 0.22^{*}$ \\
EEUHS $(200 \mathrm{mg} / \mathrm{kg})$ & $26.71 \pm 1.06^{*}$ & $0.51 \pm 0.02^{*}$ & $64.25 \pm 1.00^{*}$ & $12.61 \pm 0.23^{*}$ \\
Glibenclamide (2 $\mathbf{~ m g / k g )}$ & $25.72 \pm 0.91^{*}$ & $0.43 \pm 0.01^{*}$ & $73.75 \pm 0.83^{*}$ & $11.84 \pm 0.41^{*}$ \\
\hline
\end{tabular}

${ }^{\star} P<0.05$ when related to the diabetic control; EEUHS = ethanol extract of Uromastyx hardwickii skin; BUN = blood urea nitrogen 
insulin sensitivity. The EEUHS may have stimulated insulin secretion, since the result produced was similar to the effects of glibenclamide [4]. This finding corroborated the report on the hypoglycemic effects of Uromastyx acanthinura [19].

Treatment of the mice with STZ caused a consistent weight loss (Figure 3 ) which could be linked to polyuria, dehydration and muscle wasting [20]. STZ-induced DM is often accompanied by weight loss, linked to impaired glucose utilization and increased gluconeogenesis [20]. The gluconeogenesis involves the mobilization of muscular protein and fat from adipose tissue which predispose to weight loss. The findings indicate that EEUHS like glibenclamide reversed weight loss in the treated groups which could be via amelioration of negative energy balance.

Chronic hyperglycemia elevates advanced glycation end products (AGEP) and causes vascular complications such as nephropathy, neuropathy, stroke, myocardial infarction etc [20]. AGEP generate free radicals which cause protein fragmentation and lipid peroxidation. The product of lipid peroxidation, malondialdehyde, cause cell membrane damage and predispose to anaemia [21]. Anaemia is a common complication of DM and its effective management will improve the quality of life in affected patients [22]. Our findings indicate that EEUHS reversed anaemia in the treated groups (Table 1). This corroborated the report on the ameliorative effects of Helianthus annuus on haematological disorder in alloxan-induced hyperglycemia. The EEUHS reduced BUN and creatinine in the treated groups (Table 1). This indicates that EEUHS restored the deranged kidney function marked by elevated BUN and creatinine to near normal [23]. The mechanism of action of the nephroprotective effects of EEUHS could be via improved glucose metabolism, which reduced the liberation of AGEP that predispose to nephropathy. The improved kidney function may have elicited the reversal of the anaemia. The kidney secretes erythropoietin which stimulates erythropoiesis [22]. Dyslipidemia, characterized by hypercholesterolemia, is a complication of DM and a major risk factor of cardiovascular disease [20]. The EEUHS- and glibenclamide-treatment diminished serum cholesterol concentration in the treated groups (Table 1). This implies that EEUHS has the potential to ameliorate dyslipidemia and prevent its related complication in DM patients. The anti-dyslipidemic effects of EEUHS may be via inhibition of cholesterol absorption or biosynthesis and/or improved glucose metabolism [20].

\section{CONCLUSION}

The EEUHS possesses the potential to manage DM and its related complications (anaemia, dyslipidemia and nephropathy) in patients. However, further studies aimed to isolate the active hypoglycemic principle(s) are required.

\section{DECLARATIONS}

\section{Acknowledgement}

We are grateful to Prof IU Asuzu for proofreading the manuscript. This research was not supported by any specific grant from funding agencies in the public, commercial, or not-forprofit sectors.

\section{Conflict of interest}

No conflict of interest is associated with this work.

\section{Contribution of authors}

We declare that this work was done by the authors named in this article and all liabilities pertaining to claims relating to the content of this article will be borne by the authors. All authors read and approved the final version of the manuscript.

\section{Open Access}

This is an Open Access article that uses a funding model which does not charge readers or their institutions for access and distributed under the terms of the Creative Commons Attribution License (http://creativecommons.org/licenses/by/ 4.0) and the Budapest Open Access Initiative (http://www.budapestopenaccessinitiative.org/rea d), which permit unrestricted use, distribution, and reproduction in any medium, provided the original work is properly credited.

\section{REFERENCES}

1. Abdel-Moneim A, Bakery HH, Allam G. The potential pathogenic role of IL-17/Th17 cells in both type 1 and type 2 diabetes mellitus. Biomed Pharmacother 2018; 101: 287-292.

2. International Diabetes Federation. IDF Diabetes Atlas 9th Edition (2019). Online https://www.diabetesatlas.org/en/ (Accessed on 18th May, 2020)

3. World Health Organization. Global report on diabetes: World Health Organization. (2016). https://apps.who.i nt/iris/bitstream/handle/10665/204871/9789241565257_ eng.pdf?sequence=1 (Accessed on 18th May, 2020)

Trop J Pharm Res, March 2021; 20(3): 631 
4. Stingl H, Schernthaner $G$. The Place of Insulin Secretagogues in the Treatment of Type 2 Diabetes in the Twenty-First Century. In: Mogensen C.E. (eds) Pharmacotherapy of Diabetes: New Developments. Springer, Boston, 2007; 67-76.

5. Rutebemberwa E, Lubega M, Katureebe SK, Oundo A, Kiweewa $F$, Mukanga $D$. Use of traditional medicine for the treatment of diabetes in Eastern Uganda: a qualitative exploration of reasons for choice. BMC Int Health Hum Rights 2013; 13(1): 1 https://doi.org/10.1186/1472-698X-13-1

6. Costa-Neto EM, Motta PC. Animal species traded as ethnomedicinal resources in the Federal District, Central West Region of Brazil. The Open Complementary Medicine Journal 2010; 2: 24-30

7. Borah MP, Prasad SB. Ethnozoological study of animalsbased medicine used by traditional healers and indigenous inhabitants in the adjoining areas of Gibbon Wildlife Sanctuary, Assam, India. J Ethnobiol Ethnomed 2017; 13: 39. https://doi.org/10.1186/s13002-017-01676

8. Shams WA, Rehman G, Ullah Z, Ara S, Niaz S, Ali A, Khan K, Alam H, Gul N, Naz T, Islam S. Zootherapeutic practices in Swabi district of Khyber Pakhtunkhawa Pakistan. Pure Appl Biol 2019; 8(1): 222-231.

9. Ramesh M, Sankaran R. Natural History Observations on the Indian Spiny-tailed Lizard Uromastyx hardwickii in the Thar Desert. In: Sharma B., Kulshreshtha S., Rahmani A. (eds) Faunal Heritage of Rajasthan, India. Springer, New York, NY. 2013; 295-310.

10. Shams WA, Rehman G, Onoja SO, Ali A, Khan K, Niaz $S$. In vitro antidiabetic, anti-inflammatory and antioxidant potential of the ethanol extract of Uromastyx hardwickii skin. Trop J Pharm Res 2019; 18(10): 2109-2115.

11. National Research Council. Guide for the care and use of laboratory animals. National Academies Press 2010.

12. Selvaraj S, Palanisamy S. Investigations on the antidiabetic potential of novel marine seaweed Sargassum longiotom against alloxan-induced diabetes mellitus: $A$ pilot study. Bangladesh J Pharmacol 2014; 9: 194-197.

13. Brar RS, Sandhu HS, Singh A. Veterinary clinical diagnosis by laboratory methods. Kalyani Publishers, New Delhi (2000) 50.
14. Bartoli E, Fra GP, Schianca GC. The oral glucose tolerance test (OGTT) revisited. Eur J Intern Med 2011; 22(1): 8-12.

15. Knop FK, Vilsbøll T, Madsbad S, Holst JJ, Krarup T. Inappropriate suppression of glucagon during OGTT but not during isoglycaemic IV glucose infusion contributes to the reduced incretin effect in type 2 diabetes mellitus. Diabetologia 2007; 50(4): 797-805.

16. Lenzen S. The mechanisms of alloxan-and streptozotocin-induced diabetes. Diabetologia 2008;51(2):216-226.

17. Oboh G, Ogunsuyi $O B$, Ogunbadejo MD, Adefegha $S A$. Influence of gallic acid on $\alpha$-amylase and $\alpha$-glucosidase inhibitory properties of acarbose. J Food Drug Anal 2016; 24(3): 627-634.

18. Foretz $M$, Guigas $B$, Viollet $B$. Understanding the glucoregulatory mechanisms of metformin in type 2 diabetes mellitus. Nat Rev Endocrinol 2019; 15(10): 569-589.

19. Brito-Casillas Y, López-Ríos L, Wiebe JC, MuñozMediavilla C, Nóvoa-Mogollón FJ, Ojeda A, Wägner AM. Uromastyx acanthinura as a natural treatment in a mouse model of type 2 diabetes. Endocrinol Nutr 2016;63(1):13-18

20. Chaudhry SR, Akram A, Aslam N, Asif M, Wajid M, Kinfe $T$, Jabeen $Q$ and Muhammad $S$. Antidiabetic and antidyslipidemic effects of Heliotropium strigosum in rat models of Type I and Type II diabetes. Acta Pol Pharm 2016; 73(6): 1575-1586.

21. Vera-Aviles $M$, Vantana $E$, Kardinasari $E$, Koh $N L$, Latunde-Dada GO. Protective role of histidine supplementation against oxidative stress damage in the management of anemia of chronic kidney disease. Pharmaceuticals 2018; 11(4): 111. https://doi.org/10.3390/ph11040111

22. Stevens PE. Anaemia, diabetes and chronic kidney disease: where are we now? J Ren Care 2012; 38: 6777.

23. Wang N, Xu Z, Han P, Li T. Glycated albumin and ratio of glycated albumin to glycated hemoglobin are good indicators of diabetic nephropathy in type 2 diabetes mellitus. Diabetes Metab Res Rev 2017; 33(2): e2843. https://doi.org/10.1002/dmrr.2843 